\title{
PREVALENCE OF ANTIBODIES TO THE BK AND JC PAPOVAVIRUSES IN ISOLATED POPULATIONS.
}

J. A. N. Candeias *

R. G. Baruzzi **

S. Pripas **

M. Iunes **

RSPU-B/383

CANDEIAS, J. A. N. et al. Prevalence of antibodies to the $B K$ and $J C$ papovaviruses in isolated populations. Rev. Saúde públ., S. Paulo, 11:510-4, 1977.

ABSTRACT: A total of 173 sera from isolated Brazilian Indian populations, 39 from the Diauarun area, and 68 from the Alto Xingu area, respectively in the North and the South of the Xingu National Park and 66 Kren-Akorore Indians, were examined for hemagglutination - inhibiting (HI) antibodies against $B K$ and $J C$ viruses. The global percentages of positue sera $(\geqslant 1: 40)$ were $5.2 \%$ for $B K$ virus and $1.7 \%$ for $j C$ virus. The distribuition of positive sera according to the population groups showed one individual to be positive for $B K$ virus in the Diauarun Indians and none of the sera contained $H I$ antibody to JC virus; in the Alto Xingú Indians, 4 were positive for $B K$ virus and 3 others were positive for JC virus; as regards Kren-Akorore Indians none of the sera contained antibody to $J C$ virus, and only 4 were $B K$ positive. Due to the limited number of abservations it was neither possible to determine the time of occurrence of seroconversion nor correlate the positivity rates for both viruses in the different tribes with the respective "contact" with the white population.

Uniterus: Antibodies. Papovavirus. Polyoma virus. Indians, Brazil.

\section{INTRODUCTION}

The isolation of BK virus, a human papovavirus, from a patient with ureteric obstruction, after renal transplantation" and of another distinct virus belonging to the same group, the JC virus, from patients with progressive multifocal encephalopathy ${ }^{5}$, as well as the identification of a papovavirus related to SV40 in the brain of two patients with that encephalopathy 9 and in one patient with a malignant melanoma ", suggest that in certain circunstances, papovaviruses seem to be related to human diseases. As far as BK virus is concerned, seroepidemiologic studies of diverse populations carried out to date $1,3,4,7$ indicate that the virus is widespread, with overall prevalence in the range of $60-80 \%$. Yet there is so far no evidence that $\mathrm{BK}$ virus causes clinical symptoms. In the study of Gardner et al 2, both donor and recipient had antibodies to the virus before transplantation and the patient developed a rise in antibody titers after the operation, which might suggest an ubiquitous distribuition of $B K$ virus and a viral activation consecutive to the immunosuppressive therapy required.

- Departamento de Microbiologia e Imunologia do Instituto de Ciências Biomédicas USP "Setor Saúde Pública". Av. Dr. Arnaldo, 715 - São Paulo, SP — Brasil

* Departamento de Medicina Preventiva da Escola Paulista de Medicina - Rua Botucatu, 720 - São Paulo, SP - Brasil. 
CANDEIAS, J. A. IN. et al. Prevalence of antibodies to the BK and JC papovaviruses in isolated populations. ¿iev. Saúde públ., S. rauso, 11:510-4, 1977.

The data about JC virus, in terms of $\mathrm{HI}$ antibody, suggest a similar world wide distribution, although each virus seems to behave independently?

The purpose of this study is to determine the patterns of antibody prevalence to $\mathrm{BK}$ and $\mathrm{JC}$ viruses among isolated Brazilian Indians, using the hemagglutination-inhibition technique.

\section{MATERIAL AND METHODS}

Serum Samples - One hundred and seventy three specimens were obtained from 39 Indians living in the Diauarum area, 68 Indians living in the Alto Xingú and 66 Kren-Akorore Indians. Sera were separated in the field, and stored at $4^{\circ} \mathrm{C}$ for two or three days; they were transferred in styrofoam ice boxes to São Paulo, by air and stored at $-20^{\circ} \mathrm{C}$ until tested.

The examined population was divided into three groups according to age: 15 years and under, 16 to 35 years and 36 to 55 years. These Indians are representative of isolated populations which have their home territory south of the Amazon River. The Xingú National Park, situated in the north of the state of Mato Grosso, with an area of $22.000 \mathrm{Km}^{2}$, extends along the Xingú River from its headwaters to the von Martius waterfall, at its northern end.

The Park can be divided into two areas, according to its natural characterístics. The first to the north, is where the outpost of Diauarum is located and is largely Amazonian forest. The second to the south, is referred to as the Upper Xingú and consists predominantly of the topography of the Central Brazilian plateau-low vegetation with large expanses of plains containing many rivers and lakes.

There are 16 indigenous tribes which inhabit the Xingu National Park. They were considered, until now, to be in a relative state of isolation, many of the essentially native characteristics remaining intact.

Special reference should be made to the Kren-Akorore Indians who, until February 1973 , were in a state of complete isolation in the interior of the Amazonian forest. When a new road was planned to join Santarem in the North and Cuiabá in the soutll, through the Kren-Akorore Territory, it became urgent to contact this tribe. When this was succeded it was verified that they were living under very primitive conditions having neither canoes, ceramics, nor dogs and were using stone age axes to cut down trees. After the opening of the road the Kren-Akorore were exposed to indiscriminate contact to civilized groups causing serious repercussions on their state of health. The result was that in January 1975, they were transplanted to the Xingu National Park, $200 \mathrm{Km}$ to the East, situated in the Diauarum area. At that time they were examined by a team of physicians from the Escola Paulista de Medicina and blood was obtained for serological studies.

Hemagglutination-inhibition test - A total of 173 sera were examined for hemagglutination - inhibiting antibodies to $\mathrm{BK}$ and $\mathrm{JC}$ viruses in disposable microtiter plates (unit volumes of $0.025 \mathrm{ml}$ ) in which serial two fold dilutions were made, begining at an initial dilution of $1: 20$, in phosphate-buffered saline $\mathrm{pH}$ 7.0. All sera were treated with $\mathrm{RDE}$ and inactivated at $56^{\circ} \mathrm{C}$ for one hour.

The BK virus, was obtained from Dr. Paul Brown and inoculated in Vero cell cultures. About three weeks after inoculation, the cell cultures showing a cytopathic effect of $75 \%$ were treated for preparation of hemagglutination antigen by freeze-thaw treatment. The titer obtained was $1: 80$ and 4 hemagglutination units were used in the test. The serum-virus mixture was incubated at $37^{\circ} \mathrm{C}$ for one hour. A $0.5 \%$ suspension in phosphate-buffered saline of human group " $O$ " erythrocytes was then added and the plates were incubated at $4^{\circ} \mathrm{C}$ for one hour. A titer of at least 1:40 was considered significant.

The JC virus, was obtained from Dr. Duard Walker, as a hemagglutination antigen, with a titer of about $1: 8000$. We used an identical protocol to that used in the BK test, except that incubation of the 
CANDEIAS, J. A. N. et al. Prevalence of antibodies to the BK and JC papovaviruses in isolated populations, Rev. Saúde públ., S. Paulo, 11:510-4, 1977.

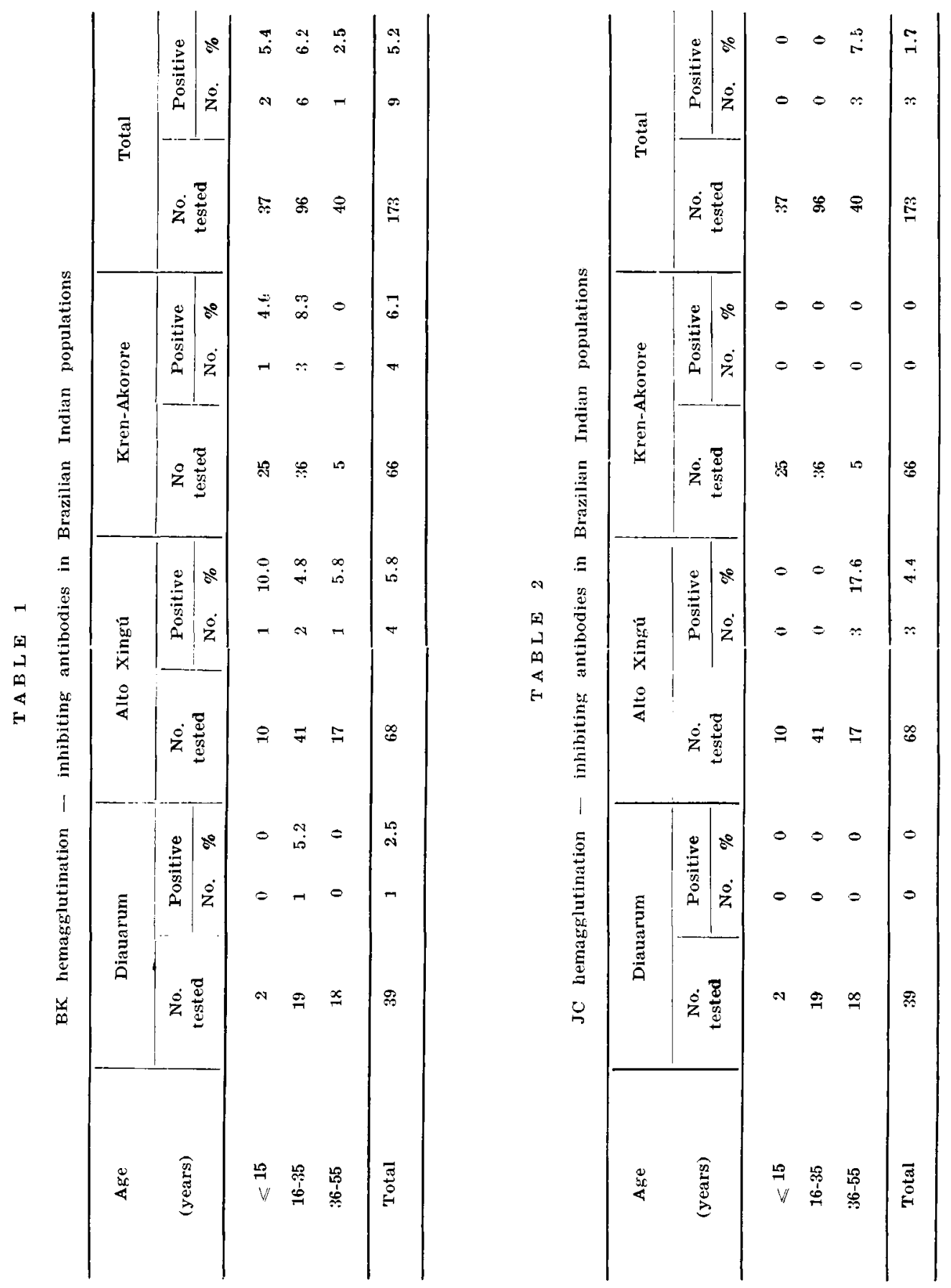


CANDEIAS, J. A. N, et al. Prevalence of antibodies to the $\mathrm{BK}$ and $\mathrm{JC}$ papovariruses in isolated populations. Rer. Saude públ., S. Paulo, 11:510-4, 1977.

serum-virus mixture was carried out at room temperature for 30 minutes. Again a titer of at least $1: 40$ was considered significant.

\section{RESULTS}

The prevalence of $\mathrm{HI}$ antibodies to $\mathrm{BK}$ and $\mathrm{JC}$ viruses in different age groups and in the population studied are shown in Tables 1 and 2 .

The overal rate of positive sera for $\mathrm{BK}$ virus was $5.2 \%$, with individual rates of $5.4 \%$ in the age group of 15 years and under and $6.2 \%$ in the age groups of 16 years to 35 years, followed by $2.5 \%$ in the eldest group. Comparing these results with the $\mathrm{JC}$ antibody prevalence rates, the major differences are easily perceived, with a overall rate of positivy of $1.7 \%$, no positive sera in the younger groups and a rate of $7.5 \%$ in the eldest group. An additional observation warrants mention. The two $\mathrm{BK}$ positive cases in the younger group were a girl aged 1 year (Alto Xingú) and a 13 year-old boy. (Kren-Akorore).

\section{DISCUSSION}

Of the 173 individuals studied $5.2 \%$ had $\mathrm{HI}$ antibodies against $\mathrm{BK}$ virus and $1.7 \%$ against JC virus, which corroborate the observations of Brown et al ${ }^{1}$ in relation $t o$ some small remote tribes of Brazil, Paraguay and Malaysia, where contact with these viruses seems to have been almost absent. This pattern is however quite different from the one we found in some cosmopolitan Brazilian groups, where $70 \%$ had HI antibodies against $\mathrm{BK}$ virus and $85 \%$ against $\mathrm{JC}$ virus*, a distribution which confirms seroepidemiologic studies in different regions of the world ${ }^{3,4,6,7}$. The study of Brown et al ${ }^{1}$, on the other hand refers a very high $\mathrm{HI}$ antibody prevalence in several populations of varying geographic isolation for $\mathrm{BK}$ and JC viruses, but considers that both viruses appear to behave independently at population as well as individual levels. In our study, although the number of positive observations is small, we never had the same individual simultaneously positive for both viruses. Probably due to the limited number of observations, in our study it was neither possible to determine the moment of occurrence of seroconversion nor to correlate the positivity rates for both viruses in different tribes with the respective "contact" with the white population.

RSPU-B/3\%:?

Candeias, J. A. N. et al. Prevalência de anticorpos contra os papovavirus $B K$ e JC em populaçóes isoladas. Rev. Saúde públ, S. Paulo, 11: 510-4, 1977 .

RESLMo: Foram estudados 173 soros de indios brasileiros, sendo 39 da área Diauarum, 68 do Alto Xingú e 66 indios Kren-Akorore. A pesquisa de anticorpos inibidores da hemaglatinação para os papovavirus $B K$ e JC mostrou uma percentagem global de positividade ( $\geqslant 40$ ) para os virus $B K$ de $5,2 \%$ e para o virus $J C$ de $1,7 \%$. A distribuição dos soros positivos segundo sua origem foi a seguinte: dos 39 indios Diallarum somente um apresentou tifulo significante para o virus $B K$ e nenham deles foi positivo para o virus $J C$; dos 68 indios do Alto Xingú, 4 apresentaram titulo significante para o virus $B K$ e 3 para o virus $J C$. sendo estes últimos diferentes dos individuos positivos para o virus $B K$ : dos 66 indios Kren-Akorore. 4 mostraram possuir titulo significante para o virus $B K$, sem positividade para o virus JC. O número reduzido de soros não permitiu estabelecer o momento da seroconservação, em termos de idade, como não permitilu relacionar as taxas de positividade com o maior oll menor "contato" com a população branca.

Unitermos: Anticorpos. Papovavirus. Virus BK. Indios brasileiros.

* Candeias, J. A. N. to be publisher. 
CANDEIAS, J. A. N. et al. Prevalence of antibodies to the BK and JC papovaviruses in isolated populations. Rev. Saúde públ., S. Paulo, 11:510-4, 1977.

\section{R E F E R E N C E S}

1. BRowN, P. et al. Seroepilemiology of human papovavirus. Discovery of virgin population and unusual patterns of antibody prevalence among remote peoples of the World. Amer. $J$. J. Epidem., 102:331-40, 1975.

2. GARDNER, S. D, et al. New human papovavirus (BK) isolated from urine after renal transplantation. Laroet, $1: 1253-7$. 1971.

3. GARDNER, S. D. Prevalence in England of antibody to human polyomavirus (BK) Brit. med. J., 1:77-8, 1973

4. MÄTYJäRVI, R. A. et al, A human papovavirus (BK), biological properties and seroepidemiology. Ann. Clin. Res,, 5:283-7, 1973.

5. PADGET, B. L. et al. Cultivation of Papova-like virus from human brain with progressive multifocal leukoencephalopathy, Lancet, 1:1257-60, 1971.
6. PADGET, B. L. \& WALKER, D. L. Prevalence of antibodies in human sera against $\mathrm{JC}$ virus, an isolate from a case of progressive multifocal leukoencephalopathy. $J$. infect. Dis., $127: 467-70,1973$.

7. SHAH, K. V. et al. High prevalence of antibodies to $\mathrm{BK}$ virus and SV40 related papovavirus in residents of Maryland. J. infect. Dis., 128:784-7. 1973.

8. SORIANO, $F$, et al. Simian virus 40 in a human cancer. Nature, 249.421-4, 1974.

9. WEINER, L. P. et al, Virus related to SV40 in patients with progressive multifocal leukoencephalopathy. New Engl. J. Med., 286 :385-90, 1972.

Reccbido para publicasão em 18/04/1977 Aprovado para publicacão em 14/0\%/1977 